\title{
Terrorism Prevention and Electoral Accountability
}

\author{
Tiberiu Dragu \\ Mattias Polborn
}

CESIFO WORKING PAPER No. 2864

CATEgory 2: Public CHOICE

DECEMBER 2009

\footnotetext{
An electronic version of the paper may be downloaded

- from the SSRN website:

- from the RePEc website:

- from the CESifo website:

www.SSRN.com

Www.RePEc.org

www.CESifo-group.org/wp
} 


\title{
Terrorism Prevention and Electoral Accountability
}

\begin{abstract}
How does electoral accountability affect the effectiveness of terrorism prevention in a democracy? We analyze the connection between electoral accountability and policy effectiveness in the context of terrorism prevention. We develop a formal model of an interaction between a government, a minority community, and a representative voter. All actors share the objective of terrorism prevention and have symmetric information. We show that electoral pressures to be successful in terrorism prevention create a commitment problem for the government and this can lead to less security. If the representative voter cares more about terrorism prevention, the government intensifies anti-terrorism activities that are under its direct control, but cooperation by the minority community weakens, and, as a result, security may decrease. We also show that commitment to ex-post suboptimal anti-terrorism activity is desirable for the government, but such commitment is difficult to achieve without explicit institutional constraints such as an effective judicial review on government's antiterrorism actions.
\end{abstract}

JEL Code: D70.

Keywords: terrorism, elections, accountability.

Tiberiu Dragu

University of Illinois

at Urbana-Champaign

tdragu@illinois.edu
Mattias Polborn

University of Illinois

at Urbana-Champaign

polborn@uiuc.edu

November 21, 2009 


\section{Introduction}

The 9/11 terrorist attacks revealed important vulnerabilities in existing terrorism policy and placed fighting terrorism at the top of most government's policy agenda. The prospect of suicide terrorism

combined with the possibility of large-scale catastrophic terrorist attacks necessitated a more active government anti-terrorism policy, and, in particular, a change from a strategy of reacting, investigating and prosecuting individuals after a terrorist attack to a strategy of terrorism prevention.

Yet, terrorism prevention is a policy issue that is not exclusively under the government's control; rather, its effectiveness also depends on the actions of other, to some extent, independent actors. Large-scale spectacular terrorist attacks need extensive preparation and planning. The communities in which terrorists have their roots can affect the probability of terror attacks in multiple ways, from the extent to which proto-terrorist activities such as fundraising for terrorist organizations or incitement to violence are considered acceptable in the community up to the direct provision of information about individuals who might be attracted to radical ideas, connected to terrorists, or actively planning a terrorist attack.

In such a setting, a more robust government anti-terror policy (say, more intensive surveillance, quicker and more extensive use of deportation for non-citizens suspected of extremist activities or, more extremely, the degree to which terrorism suspects are subjected to "enhanced interrogation") can be a two-edged sword. Even if a particular policy occasionally yields information that may disrupt terrorist organizations or specific attack plots, it also leads to alienation and antagonism in the community and may induce them to cooperate less.

Thus, there exists an important trade-off, and we analyze how this trade-off is affected by increased focus of the electorate on the issue of terrorism prevention. Democratic governments plausibly have two interrelated incentives to care about terror prevention. First, they are likely to share citizens' security concerns, and in this respect, they are perfect agents for the electorate. Second, a government that fails to prevent a terror attack is less likely to be reelected, as a defining characteristic of democracy is the power of the citizens to hold the government accountable for its policies.

We build a formal model to argue that electoral pressure to be successful in terrorism prevention can lead to less security. The negative effect may seem counterintuitive, as a core belief of democratic theory is that electoral accountability induces the government to achieve those policy outcomes preferred by voters. However, we show that increased incentives for the government to work on terrorism prevention may be counterproductive if the overall policy success does not solely depend on the actions of the government, even if all actors share the goal of preventing a terrorist attack.

The players in our game are the government, a minority community and a representative voter. The government chooses a level of anti-terrorism activities to collect information about possible terrorist threats. The minority community chooses a level of cooperation to provide the government information about possible terrorist threats. The government's and the community's actions jointly determine the likelihood of preventing a terrorist attack. Both the government and the minority 
community prefer to prevent a terrorist attack, and have a cost for their actions. However, a higher level of government anti-terror activity imposes a negative externality on the minority community. The government receives a direct benefit from preventing a terrorist attack, but also aims to be reelected. The representative voter decides whether to reelect the incumbent government and the equilibrium probability that the representative voter reelects the incumbent government depends on whether the government succeeds in preventing a terrorist attack.

The game-theoretic analysis shows that the equilibrium probability of a terrorist attack can increase if the representative voter is more likely to reelect the government if the government is more successful in preventing a terrorist attack. This is a somewhat counterintuitive result since there is no divergence of preference between the government, the minority community, and the representative voters: all actors prefer to prevent a terrorist attack. The government cares about preventing terrorism and also about reelection, and the representative voter is more likely to reelect the government if the government is more successful in preventing a terrorist attack. However, the electoral pressure creates a commitment problem: The government increases the level of antiterrorism activities under its direct control, and for a fixed level of minority community cooperation, this would decrease the probability of a terrorist attack. However, the alienation that arises as a side effect of those more aggressive anti-terrorism actions induce the community to cooperate less with the government, with the potential effect of increasing the probability of a terrorist attack.

An important issue that arises in our analysis is whether the government can commit to a particular level of counter-terrorist activities. If it can, then we show that it will use this commitment to induce the minority community to cooperate more than they would in the equilibrium of the simultaneous game. Moreover, if the government can commit, then we show that an increase in the electoral incentives to prevent a terror attack necessarily reduce the probability of a terror attack in equilibrium. However, we also show that simply "moving first" in a dynamic game does not enable the government to commit to a different level of anti-terrorist activity than is optimal ex-post (i.e., given the community's reaction), unless the activity level is perfectly and costlessly observable for the minority community. If, instead, the minority community only observes an imperfect signal of the government's anti-terror policy, then the equilibrium actions of the government and the community in the sequential game in which the government moves first are exactly the same as those in a simultaneous game. As perfect observability of actions is very implausible to be satisfied in the context of government anti-terrorist activities, this shows that, without a recourse to institutions that explicitly constrain the government's ability to implement certain policies in its fight against terrorism, commitment is very hard to achieve.

Several policy implications for the current debate regarding how liberal societies have responded to the perceived terrorist threat arise from our model. The analysis shows that excessive government targeting minority communities can arise as an equilibrium outcome even if it is counterproductive (i.e., reduces the equilibrium security level) and the government has strong electoral incentives to be successful in terrorism prevention. Our results provide a new security rationale for institutions that, at least to some extent, tie the hands of the government in its struggle against terrorism. 
For example, checks and balances on the government's antiterrorism actions such as judicial review may in fact increase the security level of a society, even if they directly inhibit some anti-terror activities of the government.

We proceed as follows. In Section 3, we discuss the contribution of this paper to the literature on democratic accountability and the political economy literature on terrorism. Section 4 presents a very simple example with binary actions that highlights the main effects. The general model and its analysis follow in Sections 5 and 6. Section 7 presents a parametric example with continuous actions, and shows exactly under which conditions the perverse effect of a decrease in equilibrium security as a result of increased electoral concerns about terrorism arises. Finally, in Sections 8 and 9, we discuss the policy implications and conclude.

\section{The Policy of Terrorism Prevention}

The main ingredient of our formal model is the interplay of government and minority community in terrorism prevention, and the potential of government actions meant to protect against terrorism to also antagonize the "minority community", jeopardizing their cooperation. In this section, we discuss the different policies of terror prevention and the causation channels that we have in mind.

We first discuss anti-terror activities that are under the direct control of the government. Although liberal democracies have experienced terrorism before $9 / 11$, the specific nature of the post 9/11 terrorist threat adds to the difficulties of terrorism prevention. In comparison with other terrorist organizations, Al Qaeda is untypical in that it is a rather loose network united by a radical ideology that inspires the formation of suicide terrorist cells both outside the borders of liberal democracies and inside the Muslim communities residing in liberal democracies.

This amorphous structure presents a difficult challenge for terror prevention. Given the openness of liberal democratic countries, it is very difficult to stop all potential terrorists at the borders, as the 9/11 attacks show. Furthermore, as sizable Muslim communities exist in most liberal democracies, governments also need to respond to the threat of homegrown terrorism, a threat evidenced by the 7/7 London attacks.

Regardless of whether the terrorist threat comes from outside or from within the country, largescale spectacular terrorist attacks need planning. The government can use a variety of different antiterrorism actions to target the resources terrorists have for planning and executing their attacks, to lower the access of terrorists to the country and to disrupt existing terrorist activities.

Internationally, the government can use a range of military actions to disrupt the recruitment, planning and training activities of terrorist organizations in certain geographical locations. For example, the United States has used military force in a counterterrorist mode in Afghanistan in an attempt to clean out one of the worlds prime terrorist safe havens and to topple a regime that has been in a close partnership with terrorist groups. In countries such as Pakistan, the CIA often uses unmanned planes ("Predator" drones) to kill suspected terrorists; this is often successful, but there are also reports of mistakes and unintended civilian casualties as a consequence of such 
operations, and large parts of the Pakistani population appear to be unhappy with the violation of their country's sovereignty.

When capturing suspected terrorists, a choice variable for the government is how intensively information is extracted from those detainees. For example, which interrogation techniques can be used on these detainees? For example, can they be subjected to sleep deprivation, waterboarding or other forms of torture, either directly by the government or after rendition to other countries? The intensity of interrogation may make a difference as to which information terror subjects are willing to divulge, but may also affect how willing other actors (whether foreign governments, or foreign or domestic individuals) are to support terrorists or to cooperate with the government in fighting terrorism.

For example, British journalist Johann Hari cites several former Islamic militants on their motivations to turn to terrorism, as well as the effects that anti-terror policies had on their recruiting efforts for terrorist organizations. ${ }^{1}$ Maajid Nawaz, a British-born islamist who moved to Egypt in 2001 and began recruiting students into radicalism, is quoted as saying: "There was an inhibiting sympathy for the victims of 9/11 - until the Bush administration began to respond with Guantanamo Bay and bombs. That made it much easier. After that, I could persuade people a lot faster."

Domestically, the government can use a range of policies that target terrorist threats at different points during the preparation and planning process of a terrorist attack. For example, in the very early stages of an attack, tougher immigration and asylum policies, such as denying entry into the country to aliens suspected of being associated with or supporting terrorist activity, may make it harder for potential terrorists to enter or to remain in the country. Most Western governments have engaged in such tougher immigration policies after 9/11. For example, in the United States, the FBI working with the Immigration and Naturalization Service arrested almost 800 individuals for immigration violations during their investigation of the 9/11 terrorist attacks (Jacobson 2006).

The government can also engage in tougher intelligence collection and surveillance activities to obtain information about terrorist threats by using some known characteristics of future terrorists from the profile of past terrorists. Since suicide terrorists have come disproportionately from certain religious and ethnic communities, any effective anti-terror intelligence and surveillance operation will focus primarily on those communities. ${ }^{2}$

After 9/11, governments in Western Europe and United State have directed their surveillance activities towards the Muslim communities. Yet, this approach is also problematic in that it alienates this community whose cooperation can be essential for terrorism prevention. For example, since the 9/11 attacks in New York, 32 percent of British Muslims report being subjected to discrimination at airports, and stops and searches of British Asians increased five times after the

\footnotetext{
${ }^{1}$ Johann Hari, "Renouncing Islamism: To the brink and back again", The Independent, November $16,2009$.

${ }^{2}$ Theoretical work on profiling show that the optimal strategy for the government is to profile on the basis of the elasticity to crime in different groups (Persico 2004). If the elasticity to engage in suicide terrorism is a lot higher in a certain community than in other segments of society, the government's optimal strategy is to focus its surveillance on that community.
} 
June 2007 attempted bombings in London and Glasgow. In Germany, police have used preventive powers to conduct mass identity checks outside major mosques. In France and Italy, raids on homes, businesses, and mosques have targeted Muslims, particularly those considered religiously observant (Open Justice Initiative 2009). In the United States, the FBI launched a mosque counting project in March 2003, in which agents were asked to document the number of mosques in their areas, in order to help measure the number of terrorism investigations that the various field offices should be expected to open and pursue. Also, before the 2004 Presidential election, the FBI launched a so-called October Plan indiscriminately "interviewing" Muslims.

In our formal model, we capture the intensity of all these government anti-terror policies by just one variable. The important point is that a more robust government policy always increases the probability of "false positives". People without evil intentions in the minority community (or others abroad with whom the minority community identifies) are likely to be inconvenienced, subjected to duress or even be killed as a consequence of government policies, and our model assumes that the way of treatment does affect the attitude of these minority communities towards the government, and that this affects their willingness to cooperate with the government.

We call the other player in our formal model the "minority community", but depending on context, this could stand for both domestic and international communities that have a special relation with (potential) terrorists, in particular in the sense that many members of terrorist organizations come from this community, that terrorists rely on support by community members.

Those communities consist mostly of people who do not wish to engage in terrorism themselves and oppose violence as a political means. They can take a range of actions to prevent terrorist attacks. First, the community can actively discourage extremism and violent activities thus increase the cost of terrorism by making less acceptable as an activity. Second, the community can discourage its members from providing active and passive support to terrorists that are actively planning an attack. Terrorists need recruits, money, tactical and organizational help to plan an attack, logistical and financial support that communities from which terrorists come could provide. Third, the community could come forth with information about terrorist activities and tip off the the government about suspicious behavior and activities. The community has better information about their members' behavior because the community members are closer to the individuals that might be attracted to radical ideas, connected to terrorists, or actively planning a terrorist attack.

Numerous researchers and security officials underscore that importance of communities for preventing terrorism. Thomas Mockaitis argues that terrorist organizations "can only be defeated with precise intelligence that allows for the highly focused and limited use of force. The intelligence can only come from the larger communities in which the insurgent terrorists operate" (Mockaitis 2003). Along the same lines, Paul Wilkinson writes that co-opting the communities to provide intelligence is the "secret of winning the battle against terrorism in an open society" (Wilkinson 2006). Similarly, a senior counterterrorism official in the Netherlands stated, "community relations are crucial to gathering information" to prevent terrorist attacks. ${ }^{3}$

\footnotetext{
${ }^{3}$ James A. Goldston and Rachel Neild. Ethnic profiling fails Europe - Editorials \& Commentary - International
} 
There is of course a trade-off here. If the government increases its antiterrorism activities directed at the community at large, distrust between the communities and the government develops. The government's antiterrorism activities directed at minority communities at large alienate these communities and makes them less likely to provide useful information to the law enforcement and intelligence agencies. There is ample anecdotal evidence that the disproportionate antiterrorism activities directed at minority communities at large has the effect of alienating these communities. For example, in the United State, Muslim groups say that surveillance techniques authorized by the Patriot Act are alienating potential allies against terrorism (Christian Science Monitor September 2009). Along the same lines, in the United States, a rift has developed between Muslims and FBI over suspicion of wide spread mosque surveillance. Islamic organizations feel betrayed by a nationwide pattern of abuse and violations of civil rights, as well as religious rights (Christian Science Monitor March 25, 2009). Moreover, the aggressive preemptive foreign policy of the United States has contributed to the alienation of the Muslim community.

\section{Existing Literature}

The paper contributes to the political economy literature on terrorism as well as the political economy literature on democratic accountability. The political economy literature on terrorism and counterterrorism addresses several critical questions about terrorism, including the structural determinants of terrorism (Li 2005; Abadie 2006; Blomberg, Hess, and Weerapan 2004; Enders and Sandler 2006), the optimal (or suboptimal) domestic or international counterterrorism policy (Enders and Sandler 1993; Rosendorff and Sandler 2004; Bueno de Mesquita 2005; Bueno de Mesquita 2007; Powell 2007a; Powell 2007b), radical mobilization (Bueno de Mesquita and Dickson 2007), terrorism recruitment and support (Bueno de Mesquita 2005; Siqueira and Sandler 2006), strategies to fight terrorism (Kydd and Walter 2006), and the internal politics of terrorist organizations (Chai 1993).

In contrast, the connection between terrorism prevention and the electoral concerns has not yet received much attention in the political economy literature on terrorism. This topic is important given that the democratic governments have to account for their policy results at the election day. In this paper, we develop a game-theoretic model to analyze the effectiveness of terrorism prevention in the context of electoral pressure. We show that an increase in the government's utility from being reelected, or an increase in the difference between reelection probabilities without and with a terror attack, can result in a deterioration of the security situation: the probability of a terrorist attack increases.

Bueno de Mesquita (2007) develops a model of interactions between voters, a government, and a suspected terrorist. Bueno de Mesquita analyzes the optimal counterterrorism policy given that counterterrorism allocations can be divided between observable and unobservable tactics. In Bueno de Mesquita's model, agency problems between the voters and government create a

Herald Tribune. 
situation in which the counterterrorism strategy pursued by the government in response to electoral and institutional incentives differs from the security maximizing counterterrorism strategy. In our model, there is no agency problem between the voter and the government, the government, the minority community and the voters all want to prevent a terrorist attack. In our model, increased electoral pressures to be successful in terrorism prevention induces the government to act in a potential suboptimal manner with the overall result of increasing the probability of a terrorist attack.

The paper also contributes to the political economy literature on democratic accountability (Manin 1997; Fearon 1999; Besley 2005). Scholars have noted two mechanisms of how elections can hold the government accountable: sanctioning and selection (Key 1966; Fiorina 1981; Manin 1997, Besley 2005; Fearon 1999). Most of the literature has been focused on analyzing the disciplining effect of elections on elected politicians or the condition under which voters prefer a trustee or a delegate representative. The exiting models fall into three categories: 1) moral hazard models, 2) adverse selection models and 3) models combining both moral hazard and adverse selection.

We develop a model to analyze the effect of increased electoral accountability on policy performance. Our model differs from the existing literature in that the government does not have full control over achieving the desired policy outcome: the government strategically interacts with the minority community, and both the government's and the minority community's action determine the likelihood of a terrorist attack. As all actors prefer to prevent a terrorist attack, there is no divergence of preference between the government, the minority community and the voters. We show that electoral accountability possibly has a negative effect on terrorism prevention because it creates a commitment problem: if preventing a terrorist attack is more important for reelection, the government increases anti-terrorist activities that are under its direct control, but this increased incentive is possibly counterproductive both for security and the agents' welfare.

\section{A simple example}

The following simple example illustrates the effect of increased electoral accountability on the effectiveness of terrorism prevention. Let all players - the government, the minority community and the voter - receive a payoff of 100 if a terror attack is prevented and a payoff of 0 if a terrorist attack occurs. In addition, the government receives a payoff of $R=200$ if it is reelected.

The government has to choose whether to engage in "normal" surveillance $\underline{s}$, or "excessive" surveillance $\bar{s}$, i.e $s \in\{\underline{s}, \bar{s}\}$. The community can choose between a low level of cooperation, $\underline{i}$, and a high level of cooperation $\bar{i}$, i.e $i \in\{\underline{i}, \bar{i}\}$. These actions translate into the following probability of a successful terrorist attack, i.e $p(s, i)$ :

Note that higher levels of $s$ and $i$ decrease the probability of a terror attack. Also, the cooperation of the minority community is quite critical here: A high level of cooperation reduces the probability of an attack by 5 percentage points, while "excessive" surveillance (relative to "normal" surveillance only reduces this probability by 2 percentage points. 


\begin{tabular}{|c|c|c|}
\multicolumn{1}{c}{} & \multicolumn{1}{c}{$\underline{i}$} & $\bar{i}$ \\
\hline$\underline{s}$ & 0.10 & 0.05 \\
\hline $\bar{s}$ & 0.08 & 0.03 \\
\hline
\end{tabular}

Table 1: Probability of a terrorist attack

The government's cost of excessive surveillance is $c_{g}=3$ and the government's cost of "normal" surveillance is $c_{g}=0$. For the minority community, the cost of low cooperation is $c_{c}=0$ and the cost of high cooperation depends on the level of surveillance chosen by the government. If the level of surveillance is normal, the community has the same cost, $c_{c}=0$. In contrast, if surveillance is excessive, the minority community has a cost of $c_{c}=10$ when choosing the high cooperation level. This modeling assumption formalizes the idea that the government's anti-terrorism action impose a negative externality on the community.

The representative voter observes whether a terrorist attack occurs or not and decides whether to reelect the incumbent government or not. We are interested in the effect of increased electoral pressure to prevent terror attacks on the overall level of security and the players' welfare. To analyze this, we compare two situations. As a benchmark, suppose that the representative voter does not condition his reelection decision on whether there is a terrorist attack or not. One can imagine this as a situation before a major terrorist attack such as 9/11 occurs so that terrorism is not on the voter's "radar screen". The voter may then be unwilling to punish the incumbent government for a terror attack that is surprising for everybody. In this situation, the voter always reelects the government regardless of whether a terrorist attack occurs or not.

In this case, the payoff matrix for government and community is given by Table $2 .{ }^{4}$

\begin{tabular}{|c|c|c|}
\hline \multicolumn{3}{|r|}{$\bar{i}$} \\
\hline$s$ & $(290,90)$ & $(295,95)$ \\
\hline $\bar{s}$ & $(289,92)$ & $(294,87)$ \\
\hline
\end{tabular}

Table 2: Payoff matrix without reelection concerns

Clearly, $\underline{s}$ is a dominant strategy for the government. The community's best reply to $\underline{s}$ is, $\bar{i}$ and so $(\underline{s}, \bar{i})$ is the unique Nash equilibrium of this game.

In the second situation, let the representative voter increase her electoral pressure on the government to prevent a terror attack: the representative voter reelects the government if and only if no terror attack occurs. In this case, payoffs are as follows.

In this situation, the government's dominant strategy is $\bar{s}$ and the community's best reply to the government strategy is $\underline{i}$. Consequently, the equilibrium of this game is $(\bar{s}, \underline{i})$.

\footnotetext{
${ }^{4}$ The payoffs can be derived as follows. Multiply 1 minus the probability of a terror attack (from Table 1) with the respective payoff from preventing an attack, and deduct the respective player's cost, if applicable. Finally, for the government, add the reelection benefit.
} 


\begin{tabular}{|c|c|c|}
\hline \multicolumn{3}{|c|}{$\underline{i}$} \\
\hline$\underline{s}$ & $(270,90)$ & $(285,95)$ \\
\hline $\bar{s}$ & $(273,92)$ & $(288,87)$ \\
\hline
\end{tabular}

Table 3: Payoff matrix with reelection concerns

It is interesting to note that all players are worse off in the above equilibrium compared to the first equilibrium: The probability of a terror attack is increased, so the voter, the minority community and the government are worse off in term of receiving the payoff from preventing a terrorist attack, and the government, in addition, pays the cost of excessive surveillance.

The problem is that the threat of being voted out of office if the government is not successful in preventing a terrorist attack creates a commitment problem. In the second situation, the government is doing more of whatever is under its direct control and as a result excessive surveillance $\bar{s}$ a dominant strategy for the government. However, this strategy induces the community to be less likely to cooperate with the government with the effect of all player being worse off.

\section{The Model}

\subsection{Description}

There are three players: the government, a minority community, and a representative voter. The government chooses a level of antiterrorism actions that we denote $s$ (for surveillance, though different interpretations are possible), and which can be chosen from $s \in[0, \bar{s}]$. The minority community chooses a level of cooperation with the government, denoted by $i$ (for information provision, though again different interpretations are possible), which is in $i \in[0, \bar{i}]$. The representative voter makes a binary decision $v \in\{0,1\}$, where 1 is interpreted as reelecting the government, and 0 as electing the opposition instead.

Terrorist activity is captured by a binary variable $T$ that takes either value 0 or 1 , where $T=1$ denotes a successful terror attack and $T=0$ its absence or failure. The actions of the government and the minority community translate into a probability of a successful terror attack, given by the function $p(s, i) \equiv \operatorname{Prob}(T=1)$. This probability decreases in both arguments, and it is convex in both $s$ and $i$ (i.e., there are decreasing marginal returns to terror prevention in both $i$ and $s: \frac{\partial^{2} p}{\partial s^{2}}>0$ and $\frac{\partial^{2} p}{\partial i^{2}}>0$. We allow for the cross partials to take any value. We say that the government's and the community's actions are substitutes if $\frac{\partial^{2} p}{\partial s \partial i}>0$ (i.e., an increase in $i$ reduces the absolute value of the marginal effect of $s$ ). Conversely, if $\frac{\partial^{2} p}{\partial s \partial i}<0$, we say that $s$ and $i$ are complements.

The timing of the game is the following. The government and the minority community make their decisions simultaneously. The representative voter then observes whether a terror attack happens and decides whether to reelect the government or not.

Let $U_{g}(T)$ be the government's direct payoff if the terror outcome is $\operatorname{Tin}\{0,1\}$. Clearly, we assume that $U_{g}(1)<U_{g}(0)$ (i.e., the government prefers that no terror attack occurs). Denote 
the difference by $\Delta_{g} \equiv U_{g}(0)-U_{g}(1)$. The government also cares about reelection and receives an additional payoff $R$ if and only if reelected. Finally, a function $c_{g}$ measures the cost of the government from engaging in preventive surveillance to foil a terrorist attack. Apart from tangible costs of antiterror actions, $c_{g}(s)$ can also be thought of as including the psychological discomfort of surveillance measures for (majority) citizens. In summary, the government's expected utility is

$$
(1-p(s, i)) \cdot\left[U_{g}(0)+R \cdot E(v \mid T=0)\right]+p(s, i)\left[U_{g}(1)+R \cdot E(v \mid T=1)\right]-c_{g}(s),
$$

where $E(v \mid T)$ is the reelection probability given the realization of $T$.

The anti-terrorism activity of the government, $s$, imposes a negative externality on the minority community. To formalized this notion, we assume that the minority community's utility $U_{c}(T, s)$ is decreasing in $s$, as $s$ infringes on the civil liberties of the minority community. Furthermore, we assume that an increased level of surveillance antagonizes the community and induces them to care relatively less about terror prevention (we discuss this assumption in more detail below). Technically, we assume that $\Delta_{c}(s) \equiv U_{c}(0, s)-U_{c}(1, s)>0$ (i.e., the community shares the objective to prevent terror attacks), but $\Delta_{c}^{\prime}<0$ (increased surveillance and the resulting antagonism reduce the degree to which the minority community shares the social objective of terror prevention). The function $c_{c}$ measures the cost of the minority community to provide information to the government. We assume that the cost function is strictly convex $\left(\frac{\partial^{2} c}{\partial i^{2}}>0\right)$ In summary, the minority group's expected utility is

$$
p(s, i) \cdot U_{c}(1, s)+(1-p(s, i)) \cdot U_{c}(0, s)-c_{c}(i)=U_{c}(0, s)-p(s, i) \Delta_{c}(s)-c_{c}(i) .
$$

Alternatively, the negative externality of the government's anti-terrorism actions on the minority community could have been formalized by assuming that the social objective of stopping a terrorist attack is independent of $s$ but that the marginal cost of the minority community for cooperating with the government increases with an increase in $s$. That is, the minority community has a cost for cooperating with the government $c_{c}(i, s)$ with a positive cross-partial, $\frac{\partial^{2} c}{\partial i \partial s}>0$. The idea is that community members dislike it the more to report on the suspicious activities of fellow community members the more aggressive the government is in its anti-terror policy. Both formulations of the idea of a negative externality are plausible. In the analysis, we use the first formulation but the results are exactly the same if we use the second formulation.

The representative voter receives a utility $U_{V}(T, E)$ from reelecting the government, and utility $U_{V}^{0}$ from electing the opposition. Here, $E$ is the performance of the government in areas other than terrorism prevention (such as the economic performance of the government), which is a random variable at the time that the government chooses $s$. We assume that $U_{V}$ is decreasing in $T$. Since the voter reelects the government if and only if $U_{V}(T, E) \geq U_{V}^{0}$, the probability that the voter reelects the government if $T=0$, denoted $q_{0}$ is larger than the probability that the voter reelects the government if $T=1$, denoted $q_{1}$. 


\subsection{Discussion of modeling assumptions}

Congruence of objectives. All three actors share the objective of preventing a terror attack. In particular, one can think of the government's and the voter's objectives as being closely aligned: In fact, the terms $\Delta_{g}$ and $c_{g}$ in the government's objective function could be derived from the citizens' utility. In this context, $c_{g}$ may be interpreted as the monetary costs of terror prevention, but can also include citizens' dislike of antiterror methods that infringe on civil liberties of minority communities.

The only divergence of objectives between the government and the voter arises from the fact that the government is also interested in its reelection. Yet, since the prevention of a terror attack is instrumental for the government's reelection bid, this divergence of objectives does not appear to be particularly severe.

The government/voter and the minority community share the objective of preventing a terrorist attack but the government's level of anti-terrorism activities imposes a negative externality on the minority community. In the formulation we work with, the government's action affects the intensity with witch the minority community prefers to prevent a terrorist attack. Note that, even though the government's antiterrorism decreases the minority community's intensity of preferring to prevent a terrorist attack in our formulation, we can allow for the minority community to have a higher preference than the government for stopping terrorist attacks (if we were to make cardinal comparisons of utility).

Voter behavior. The main focus of our model is not to advocate a specific model of voter behavior, which is why we model voters in a reduced form by assuming that the representative voter's utility from reelecting the incumbent government decreases when a terrorist attack occurs, so that a terror attack lowers the reelection probability of the incumbent government. Several microfoundations are consistent with such a decrease in the reelection probability, which is all we need from the voting stage for the analysis of the interaction between government and minority community. Gassebner et al. (2007) provide empirical evidence for a systematic connection between terrorism prevention and election outcomes. They examine this relationship using a large data set consisting of more than 800 elections in 115 countries over the period 1968-2002. Their empirical results shows that terrorism increases the probability that the incumbent government is replaced at the next election. The probability of a government change depends on the severity of the terrorist attack. Terrorist attacks without casualties or injuries increase the probability of a government change by only $1.3 \%$, while terrorist attacks with at least one casualty increase the probability of a government change with $20.3 \%$.

A voting rule that reduces the reelection probability of the government after a terrorist attack is consistent with both a retrospective and a prospective voting behavior and we do not need to take any position on whether the voters decide retrospectively or prospectively. In a retrospective voting interpretation, a terrorist attack decreases the voter's welfare, and the voter punishes the incumbent government for the reduction in his welfare. 
Alternatively, it is also possible to derive the same voter behavior in a framework in which voters are forward-looking, but update their beliefs about the unknown level of the government's competence by taking past performance into account. For example, suppose that the government can either be "high ability" or "low ability" with respect to preventing terror attacks. Ceteris paribus (i.e. given equilibrium actions), high ability reduces the probability of a terror attack. Since the occurrence of a terror attack is more likely if the government is less competent, the voter rationally takes the occurrence of a terror attack as a bad signal for the incumbent government's quality, and thus only votes for the incumbent government if performance in other areas outweighs this negative effect. Consequently, a terror attack also decreases the reelection probability of the government in this setup with purely forward-looking voters.

Sequence of moves. We assume that the government and the minority community make their choices simultaneously. Effectively, this sequence prevents the government from committing to a level of anti-terror activity that is not ex-post optimal from the perspective of maximizing the government's objective function. We return to the issue of whether it is plausible that the government can commit in Section 6.3, where we show that commitment would require perfect and completely costless observability of the government's actions by the community.

Alternatively, our model can be interpreted as a shortcut for a full dynamic model in which behavior of the minority community depends on the government's behavior in the previous period. In such a setup, the government has at least some incentive to disregard the negative consequences that increasing $s$ has on future cooperation by the minority community, as the government is primarily concerned with preventing a terror attack "on its watch" in the present period, rather than with the long run consequences that may materialize later (and under a different government).

No terrorist organization as player. While our model is concerned with the prevention of terrorist attacks, we do not have a terror organization as a strategic player in the game. This setup allows us to focus the model on the interaction between the electorate, the government and the minority community. Moreover, we could easily extend the model to have a terrorist cell whose attack possibilities depend on the strategies of the government and the minority community, and which has an unknown outside option. This terrorist group would choose to attack if and only if the probability that the attack is successful given its resources, multiplied with the value that the terrorists attach to a successful attack, is larger than their outside option. We can think of the function $p(s, i)$ to be a reduced form of such a model with a strategic terrorist player.

Utility function of the minority community. In our model we assume that the minority community shares the objective of preventing a terrorist attack. However, it is possible that the community might have some preference for terrorism depending on the application of the model. For example, consider an occupied country such as Iraq or Afghanistan. If the occupation army fights insurgents in a more active way, the risk of hitting innocent civilians increases and this leads to stronger alienation between the occupation force and the population and also to possibly the 
community offering stronger support to the insurgents. In this case, $i$ can measure the absence of active support for the insurgent or terrorist organization, rather than the direct support of the government's fight against the terrorists. Higher levels of government suppression may induce some individuals to become terrorists, and make joining a terrorist organization a more acceptable or even respected behavior in the community. The trade-off between active insurgency fighting and risking the support of the population is the same as in our model.

\section{Analysis}

\subsection{Equilibrium}

We now analyze the equilibrium of our game. As already mentioned in the model section, voter behavior at the election stage results in an ex-ante expected probability that the government is reelected if there is no terror attack, $q_{0}$, and an ex-ante expected probability that the government is reelected if there is a terror attack, $q_{1}<q_{0}$. It is useful to let $Q \equiv q_{0}-q_{1}$ denote the equilibrium effect of a terror attack on the government's reelection probability implied by voter behavior. In the remainder, we can therefore focus on the interaction between government and minority community.

Substituting $q_{i}=E(v \mid T=i)$ in (1) and rearranging gives the government's objective function

$$
U_{g}(0)+q_{0} R-p(s, i)\left[\Delta_{g}+Q R\right]-c_{g}(s)
$$

Maximizing this with respect to $s$ implies that the government's optimal action is the solution of the following first order condition:

$$
-\frac{\partial p(s, i)}{\partial s} \cdot\left[\Delta_{g}+Q R\right]-c_{g}^{\prime}(s)=0
$$

The optimization problem of the government is strictly concave in $s$, as the second derivative is $-\frac{\partial^{2} p(s, i)}{\partial s^{2}}\left[\Delta_{g}+Q R\right]-c_{g}^{\prime \prime}(s)<0$. Thus, there is a unique optimal level of $s$ for any given level of $i$; as a consequence, the government has a well-defined optimal response function. Moreover, as (4) is continuous in $i$, the government's best response function is continuous and we can apply the implicit function theorem to (4) to find its slope is

$$
\frac{d s}{d i}=-\frac{-\frac{\partial^{2} p(s, i)}{\partial s \partial i}\left[\Delta_{g}+Q R\right]}{-\frac{\partial^{2} p(s, i)}{\partial s^{2}}\left[\Delta_{g}+Q R\right]-c_{g}^{\prime \prime}(s)} .
$$

Since the denominator is negative and both terms in square brackets are positive, the sign of $d s / d i$ is the opposite of the sign of $\frac{\partial^{2} p(s, i)}{\partial s \partial i}$. Thus, if government surveillance and community cooperation are substitutes in preventing terror attacks, the optimal level of $s$ decreases as $i$ increases, and if they are complements, then the optimal level of $s$ increases as $i$ increases.

The minority community's expected utility given in (2) is maximized over $i$, and its optimal 
action is the solution of the first order condition

$$
-\frac{\partial p(s, i)}{\partial i} \Delta_{c}(s)-c_{c}^{\prime}(i)=0 .
$$

The minority community's objective function is strictly concave in $i$, as the second derivative with respect to $i$ is $-\frac{\partial^{2} p(s, i)}{\partial i^{2}} \Delta_{c}(s)-c_{c}^{\prime \prime}(i)<0$, because all terms are negative. By the same arguments as above, the minority community's best response function is continuous, and we can apply the implicit function theorem to (6) to find its slope is

$$
\frac{d i}{d s}=-\frac{-\frac{\partial^{2} p(s, i)}{\partial i \partial s} \Delta_{c}(s)-\frac{\partial p}{\partial i} \Delta_{c}^{\prime}(s)}{-\frac{\partial^{2} p(s, i)}{\partial i^{2}} \Delta_{c}(s)-c_{c}^{\prime \prime}(i)} .
$$

The second term in the numerator is negative. Thus, a sufficient (but not necessary) condition for $\frac{d i}{d s}<0$ is $\frac{\partial^{2} p(s, i)}{\partial i \partial s}>0$, i.e., the government's and the community's actions are substitutes. If instead $i$ and $s$ are complements, then the sign of $\frac{d i}{d s}$ depends on the size of the countervailing effects.

The results so far imply the following proposition.

Proposition 1. The simultaneous game has a Nash equilibrium in pure strategies.

Proof. Follows immediately from the fact that the best response functions are continuous and the strategy spaces are bounded.

It is useful to focus on a setting where the pure strategy Nash equilibrium is stable. That is, suppose we start with a pair of strategies $\left(s_{0}, i_{0}\right)$ that are sufficiently close to, but different from a Nash equilibrium $\left(s^{*}, i^{*}\right)$. If a sequence of best responses converges towards the equilibrium, we say that $\left(s^{*}, i^{*}\right)$ is stable.

Definition 1. For given $\left(s_{0}, i_{0}\right)$, define the sequence $\left\{\left(s_{t}, i_{t}\right)\right\}_{t=1, \ldots, \infty}$ recursively as follows: Let $s_{t}=s\left(i_{t-1}\right)$ and $i_{t}=i\left(s_{t}\right)$. The Nash equilibrium $\left(s^{*}, i^{*}\right)$ is locally stable if there exists $\varepsilon>0$ such that, whenever $\left\|\left(s_{0}, i_{0}\right)-\left(s^{*}, i^{*}\right)\right\|<\varepsilon$, then $\lim _{t \rightarrow \infty}\left\{\left(s_{t}, i_{t}\right)\right\}=\left(s^{*}, i^{*}\right)$.

For example, suppose that $i$ and $s$ are substitutes in preventing a terrorist attack. In this case, both reaction functions are downward-sloping. A Nash equilibrium is locally stable if the reaction function $s(\cdot)$ is steeper than the reaction function $i(\cdot)$ at the equilibrium. Figure 1 shows the convergence to the equilibrium starting from an initial point $\left(s_{0}, i_{0}\right)$.

One can also easily check that, if $i$ and $s$ are substitutes and $i(\cdot)$ is steeper than $s(\cdot)$, then the equilibrium is unstable. Furthermore, if $i^{\prime}<0$ and $s^{\prime}>0$, then the equilibrium is stable, and if both $i^{\prime}>0$ and $s^{\prime}>0$, then $s(\cdot)$ has to be steeper than $i(\cdot)$ for the equilibrium to be stable.

While stability is not a property of the equilibrium that is implied by our assumptions, it is a very natural feature of the equilibrium. For example, in the case of substitutes, the equilibrium is stable if the government's optimal action does not change too drastically with the level of cooperation $i$ chosen by the community. In the following comparative statics analysis, we focus on stable equilibria. 


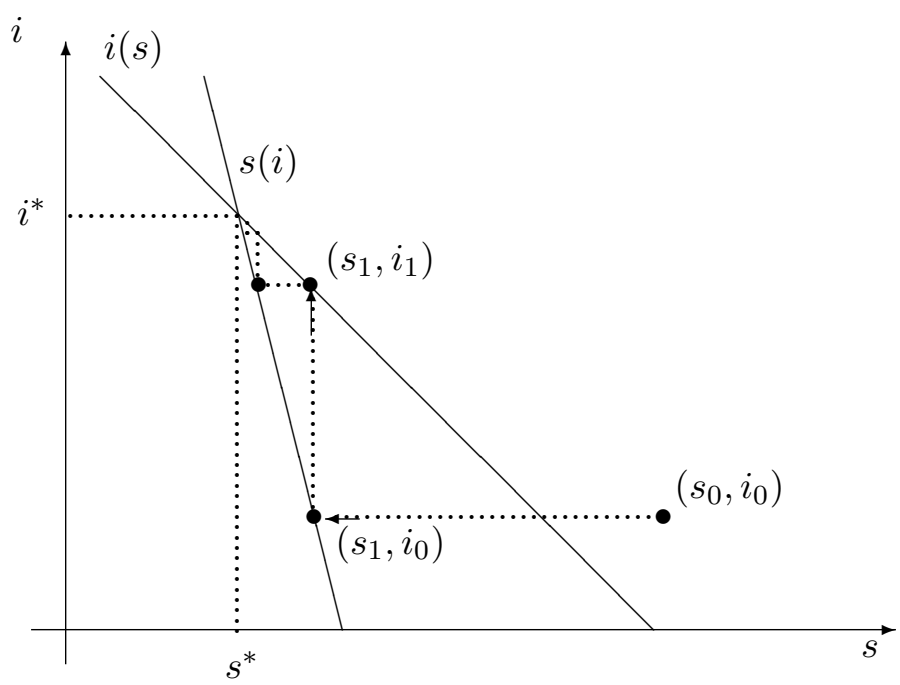

Figure 1: A stable equilibrium if $i$ and $s$ are substitutes

Consider now how the equilibrium actions change in response to increased electoral incentives to prevent a terror attack. Figure 2 shows the two reaction functions $i(s)$ and $s(i)$ for the case that $i$ and $s$ are substitutes in preventing a terrorist attack so that both reaction functions are downward-sloping.

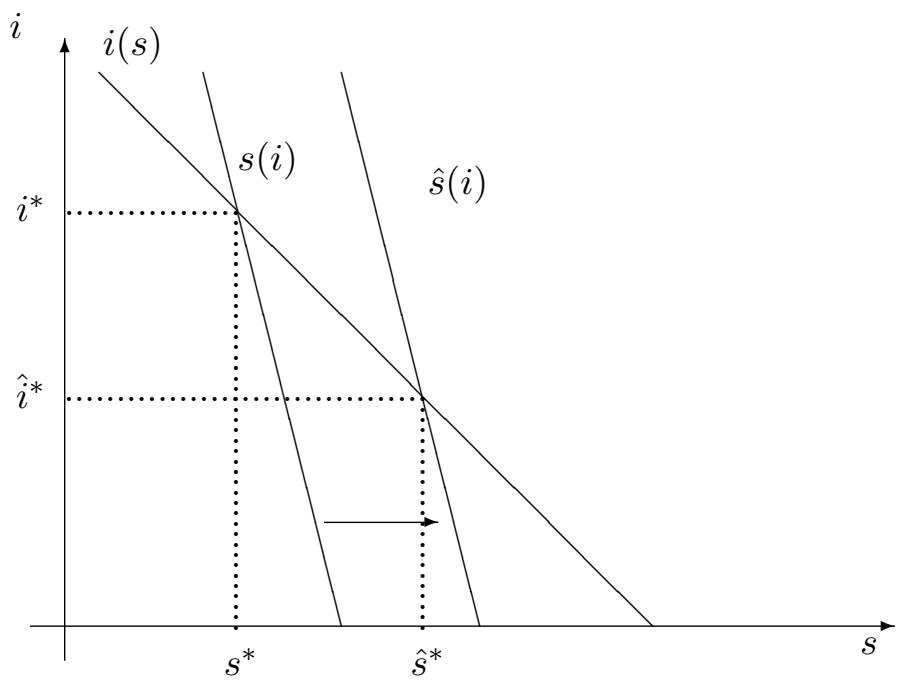

Figure 2: Reaction functions and equilibrium if $i$ and $s$ are substitutes

Since (3) is concave, a sufficient condition for a parameter change to increase the optimal $s$ (for any level of $i$ ) is that the parameter change increases the left-hand side of (4). From this argument it follows that an increase in the electoral incentives (i.e., in $\Delta_{g}+Q R$ ), or a decrease in the government's marginal cost function $c_{g}^{\prime}$, shifts the government's reaction function to the right: Given any fixed level of $i$, the government now prefers to choose a higher level of $s$ (function $\hat{s}(i$ ) in Figure 2). 


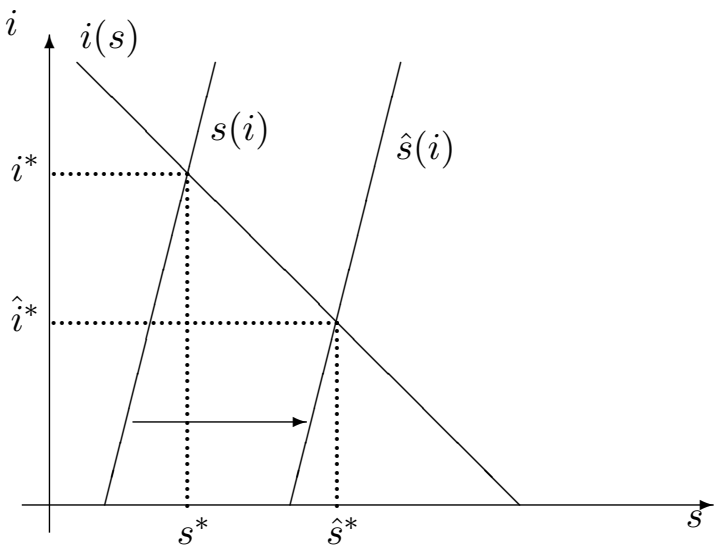

(a) $i^{\prime}(s)<0$

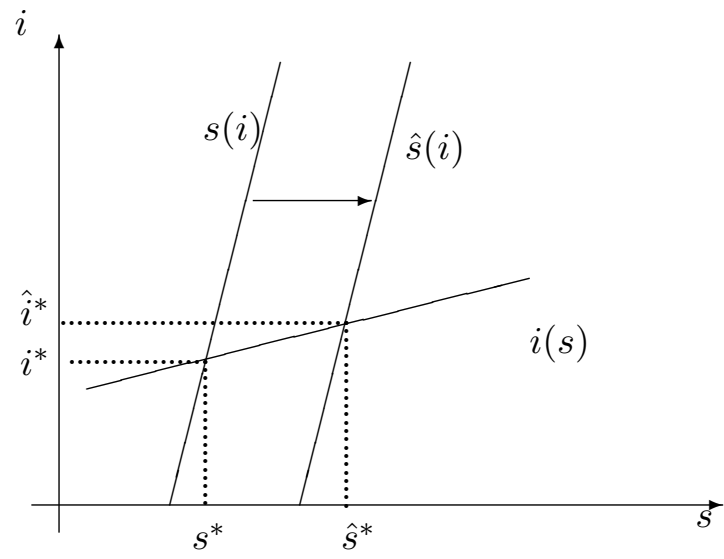

(b) $i^{\prime}(s)>0$

Figure 3: Reaction functions and equilibrium if $i$ and $s$ are complements

As a consequence, the equilibrium changes from $\left(s^{*}, i^{*}\right)$ to $\left(\hat{s}^{*}, \hat{i}^{*}\right)$. Thus, while the equilibrium value of $s$ increases, the equilibrium value of $i$ decreases, and thus the effect on the overall probability of a failing to prevent a terrorist attack is unclear. In fact, in a parametric example in Section 7 , we provide conditions under which this probability increases or decreases.

Figures 3(a) and 3(b) show the comparative static effects for the case that $s$ and $i$ are complements $\left(\frac{\partial^{2} p}{\partial s \partial i}<0\right)$. Note that the shift of the government's reaction function to the right is independent of whether $\frac{\partial^{2} p}{\partial s \partial i}$ is positive or negative.

As argued above, when $s$ and $i$ are complements, the reaction function of the government is always upward-sloping, while the slope of the community's reaction function may still be negative (this is the case when the negative externality of $s$ on $\Delta_{c}$ is large) or positive (in the opposite case)

The following Proposition 2 summarizes the comparative static effect of a small change in the electoral incentives on the equilibrium values of the choice variables and the security level

Proposition 2. Assume that the equilibrium is locally stable and suppose that the government's incentives for anti-terror activity increase, i.e. $\Delta_{g}, Q$ or $R$ increase, or that the marginal cost of surveillance decreases.

1. If $\frac{\partial^{2} p}{\partial s \partial i}>0$ (i.e., if $i$ and $s$ are substitutes), then the equilibrium level of $s$ increases and the equilibrium value of $i$ decreases. The overall effect on the equilibrium probability of a terror attack is ambiguous.

2. If $\frac{\partial^{2} p}{\partial s \partial i}<0$ (i.e., if $i$ and $s$ are complements) and the reaction function of the minority, $i(s)$ is downward-sloping, then the equilibrium level of $s$ increases and the equilibrium value of $i$ decreases. The overall effect on the equilibrium probability of a terror attack is ambiguous.

3. If $\frac{\partial^{2} p}{\partial s \partial i}<0$ (i.e., if $i$ and $s$ are complements) and the reaction function of the minority, $i(s)$ is upward-sloping, then the equilibrium levels of $i$ and $s$ increase, and the probability of a terror attack decreases. 
Proof. See text above.

Proposition 2 shows that increased incentives for the government always increase the equilibrium level of $s$, even if we take the reaction of the minority community into account. However, the security-enhancing aspect of a higher $s$ is counteracted by a reduction of the equilibrium level of $i$, as long as the minority community's reaction function is downward sloping. The overall effect on the security level therefore depends on which of these effects is more important. Only if the reaction function of the community is upward-sloping (i.e., the optimal level of cooperation for the minority community increases when the government chooses a higher level of $s$ ), then the direct effect of the incentives on the government and the strategic effect on the minority community go in the same direction, and the probability of a terror attack is unambiguously reduced.

\subsection{Commitment by the Government}

The above analysis shows that increased anti-terror activity by the government possibly has the undesired consequence of alienating the minority community, and that increased electoral incentives to prevent a terror attack may result in the perverse effect of making such an attack more likely to occur. In such a setting, it appears desirable if the government could constrain itself from being too intrusive and ex-ante commit to a particular value of $s$. One way of modeling such commitment is by assuming that the government moves first and the community observes $s$ before deciding on $i$.

As we prove in the appendix, the result that the equilibrium level of $i$ is weakly greater in the sequential game than in the simultaneous game holds for general functional forms.

Proposition 3. Suppose that the government can commit to a level of $s$ that is observed before the minority community chooses its action. In this case, the equilibrium level of cooperation by the community, $i$, is larger than in the game in which government and community move simultaneously.

Proof. See Appendix.

Thus, in contrast to the simultaneous game, it is guaranteed in the sequential game that an increase in the incentives of the government to prevent a terror attack translates into a reduced equilibrium probability of a terror attack. As we show in the Appendix, this result holds generally, independent of the specific functional forms:

Proposition 4. Suppose that the government can commit to a level of s that is observed before the minority community chooses its action. In this case, an increase in the incentives of the government to prevent a terror attack (at least weakly) decreases the equilibrium probability of a terror attack.

Proof. See Appendix.

\subsection{Commitment, First Move and Observability}

The previous subsection shows that if the government commits to an action, an increase in the government's incentives to foil a terrorist attack leads to a lower probability of such an attack. The 
sequential game also gives a payoff to the government that is at least as large as its payoff in the game where community and government move simultaneously. This raises the question of how the government can implement commitment in practice. The main point that we want to make in this section is that commitment in the context of government anti-terrorism activity and infringement on civil liberties requires some constitutional or legal constraints on the government, together with a credible enforcement of these rules by the judiciary. In contrast, if we amend the framework of the game in a realistic way, a simple change in the order of moves to a sequential one is unlikely to lead to an outcome that differs from the outcome of the simultaneous game.

In the previous subsection, we assume that the minority community can exactly and without cost observe the exact level of anti-terrorist policy chosen by the government. In the context of antiterrorism, it would certainly appear that this assumption is unrealistic as a literal interpretation, because many anti-terrorism actions require a certain secrecy to be effective at all. Thus, it is important to analyze what would happen in a sequential game if we relax the assumption of exact observability and instead assume that the minority group receives a signal that is correlated (but not perfectly so) with the government's action. The logic of our argument follows Bagwell (1995).

Specifically, suppose that for any action $s$ the government chooses, the minority community observes the realization $x$ of a random variable $X$ which stochastically depends on the action $s$. We assume that the conditional probability density function $j(x \mid s)$ satisfies $j(x \mid s)>0$ for all $x \in X$ and $s \in[0, \bar{s}]$. For example, suppose that $X=s+\varepsilon$, so that the signal $x$ is equal to the true value $s$ plus an "observation error" $\varepsilon$ that could be distributed according to a normal distribution $N\left(0, \sigma^{2}\right)$. Denote by $\mu(x, y)$ the minority community's posterior belief that the government's action $s$ is no larger than $y$, conditional on observing the signal $x$. Since every value of $x$ arises on the equilibrium path, all beliefs are pinned down by Bayes' rule. A pure strategy of the minority community in this framework is a function $i_{\text {seq }}(\cdot)$ that maps signals $x$ into actions.

Proposition 5. A pair of strategies $\left(s^{*}, i_{\text {seq }}(\cdot)\right)$ is a pure strategy perfect Bayesian equilibrium of the sequential game with imperfect observability if and only if $i_{\text {seq }}(x)=i^{*}$ for all $x$, and $\left(s^{*}, i^{*}\right)$ is a pure strategy equilibrium of the simultaneous game.

Proof. See Appendix.

Intuitively, in any pure strategy equilibrium, the minority community correctly anticipates the government's equilibrium action, and therefore its own equilibrium action is independent of the signal observed. But then, if the government anticipates that the minority community's equilibrium action is independent of the signal the community observes it chooses its best response for the given minority community's equilibrium action. Thus, only actions $s^{*}$ and $i^{*}$ that are best replies to each other are can arise on the equilibrium path of the sequential game with imperfect observability.

A similar argument for the equivalence of the simultaneous and the sequential game can be made by assuming that the government's action is not costlessly observable, but rather that the minority community has to choose whether to pay a (possibly arbitrarily small) cost $\epsilon$ to observe the government's action. In this case, the only pure strategy equilibria are the ones of the simultaneous 
game. To see this, note that in a pure strategy equilibrium, the minority community has no incentive to pay the observation cost and thus will choose an action that is independent of the actual action of the government. But in that case, the government will choose its optimal response against the expected action of the minority community, and therefore the only equilibrium actions are those that are equilibrium actions in the simultaneous version of the game.

In summary, these results strongly suggest that the government cannot expect to commit to an ex-post suboptimal level of $s$, if $s$ is not perfectly and costlessly observed. Furthermore, perfect and costless observability is a very implausible assumption for the issue of government anti-terror measures, and thus the equilibrium of the game in which government and minority community move simultaneously appears to be the plausible equilibrium if there are no other explicit commitment mechanisms.

\section{A parametric example}

The following simple parametric example analyzes a setting in which $i$ and $s$ are substitutes. It allows us to analyze precise conditions (within the framework of the example) under which the probability of a terror attack decreases or increases with electoral incentives.

We assume that $p(s, i)=\alpha e^{-s}+(1-\alpha) e^{-i} .5$. Furthermore, the cost functions are linear in $s$ and $i$, respectively: $c_{g}(s)=k_{g} s$ and $c_{c}(i)=k_{c} i$. The utility of the community in case of an attack is $U_{c}(1, s)=\bar{u} /(1+s)$, while it is $U_{c}(0, s)=(\bar{u}+\delta) /(1+s)$ in case of no attack. Note that $s$ reduces the community's utility in both states, and that the difference between the utility in both states, $\delta /(1+s)$, is also decreasing in $s$.

\subsection{Simultaneous Interaction}

We first consider what happens when government and minority community move simultaneously. The government's problem is

$$
\max _{s}\left[1-\alpha e^{-s}-(1-\alpha) e^{-i}\right]\left(\Delta_{g}+Q R\right)-k_{g} s
$$

Solving the first order condition of the government's optimization problem yields

$$
s=\ln \left(\frac{\alpha\left(\Delta_{g}+Q R\right)}{k_{g}}\right)
$$

as the government's optimal action (provided that this is positive, and $s^{*}=0$ otherwise). Note that this level of $s$ is independent of the level of $i$ chosen by the community.

The minority community maximizes

$$
\max _{i}\left[1-\alpha e^{-s}-(1-\alpha) e^{-i}\right] \frac{\delta}{1+s}-k_{c} i
$$

\footnotetext{
${ }^{5}$ This specification can be interpreted as one in which government and community actions each affect different "areas", in which the probability of an attack cannot be affected by the other player.
} 
Solving the first order condition of the minority community for $i$ yields

$$
i(s)=\ln \left(\frac{(1-\alpha) \delta}{k_{c}(1+s)}\right)
$$

as the reaction function, so that the equilibrium level of $i$ is

$$
i^{*}=\ln \left(\frac{(1-\alpha) \delta}{k_{c}}\right)+\ln \left(\ln \left(\frac{k_{g}}{\alpha\left(\Delta_{g}+Q R\right)}\right)\right)
$$

provided that this is positive, and $i^{*}=0$ otherwise. From now on, we focus on an interior equilibrium in which $s^{*}>0$ and $i^{*}>0$. Substituting the equilibrium values into $p(\cdot)$, the probability of a successful terror attack is

$$
p\left(s^{*}, i^{*}\right)=\frac{k_{g}}{\Delta_{g}+Q R}+\frac{k_{c}}{\delta}\left(1+\ln \left(\frac{\alpha}{k_{g}}\right)+\ln \left(\Delta_{g}+Q R\right)\right)
$$

in equilibrium. Differentiating with respect to $\Delta_{g}+Q R$ yields

$$
\frac{\partial p\left(s^{*}, i^{*}\right)}{\partial\left(\Delta_{g}+Q R\right)}=-\frac{k_{g}}{\left(\Delta_{g}+Q R\right)^{2}}+\frac{k_{c}}{\delta} \frac{1}{\left(\Delta_{g}+Q R\right)}
$$

This is positive if and only if

$$
\frac{\Delta_{g}+Q R}{\delta}>\frac{k_{g}}{k_{c}}
$$

Thus, if the ratio of the "valuations" that the government and the minority community get from preventing a terror attack, respectively, is already larger than the ratio of the cost parameters, then a further increase in the government's incentives to prevent a terror attack (i.e., in either $\Delta_{g}$, or $Q$, or $R$ ) actually increases the equilibrium probability of one occurring.

Intuitively, an increase in the government's incentives increases the equilibrium value of $s$ (see (9)), but the increased $s$ decreases the cooperation that can be obtained from the minority group. The dilemma of the government is that, while a higher level of $s$ prevents some terror attacks, it also increases the cost for the minority to cooperate and thus decreases the level of cooperation. As shown, this strategic effect may outweigh the direct benefit of higher government motivation.

Note that (15) is independent of $\alpha$, which is surprising, as it would appear intuitive that the "perverse" effect of electoral incentives lowering the equilibrium security level is more (less) likely to obtain if the importance of the minority community's action is large (small). Indeed, the result that (15) is independent of $\alpha$ only obtains in an interior equilibrium, and for extreme values of $\alpha$ only one of the players chooses positive effort. If $\alpha \rightarrow 1$, i.e. almost only the government's actions matter for effective terror prevention, then $i^{*}=0$, as the right-hand side of (12) is negative. In this case, an increase of $\Delta_{g}+Q R$ has only the direct effect of increasing $s$, while the strategic effect on $i$ is zero. Thus, for $\alpha$ close to 1 , stronger electoral incentives necessarily lower the equilibrium probability of an attack. In this sense, the interesting "perverse" comparative static effect requires that the effect of the minority community's actions is sufficiently strong. However, once this importance 
reaches a certain threshold so that the equilibrium is interior, the direction of the electoral effect is independent of $\alpha$.

\subsection{Sequential Interaction}

If the government can commit to a level of $s$ which is perfectly and costlessly observable by the minority community, then the optimal action of the minority community is given by (11). Note that $i^{\prime}(s)=-1 / s<0$. The government's optimization problem is therefore

$$
\max _{s}\left[1-\alpha e^{-s}-(1-\alpha) e^{-i(s)}\right]\left[\Delta_{g}+Q R\right]-k_{g} s
$$

Differentiating with respect to $s$ gives

$$
\left[\alpha e^{-s}+(1-\alpha) e^{-i(s)} i^{\prime}(s)\right]\left[\Delta_{g}+Q R\right]-k_{g}=0 .
$$

Substituting for $i(s)$ and $i^{\prime}(s)$ yields

$$
s=\ln \left(\frac{\alpha}{\frac{k_{c}}{\Delta_{c}}+\frac{k_{g}}{\left[\Delta_{g}+Q R\right]}}\right)
$$

and substituting this value into the minority group's reaction function yields

$$
i=\ln \left(\frac{(1-\alpha) \Delta_{c}}{k_{c}}\right)-\ln \left(\ln \left(\frac{\alpha}{\frac{k_{c}}{\Delta_{c}}+\frac{k_{g}}{\left[\Delta_{g}+Q R\right]}}\right)\right)
$$

along the equilibrium path. Comparing (18) with (9) shows that the government's optimal level of $s$ is lower in the sequential game, and hence (using $i^{\prime}(s)<0$ ), the equilibrium value of $i$ is higher in the sequential game. Thus, from the point of view of minimizing the probability of a terror attack, a sequential game has advantages and disadvantages.

Substituting in $p$, we have that the probability of a successful terror attack in the sequential game is

$$
p_{\text {seq }}=\frac{k_{g}}{\left[\Delta_{g}+Q R\right]}+\frac{k_{c}}{\Delta_{c}} \ln \left(\frac{\alpha e}{\frac{k_{g}}{\left[\Delta_{g}+Q R\right]}+\frac{k_{c}}{\Delta_{c}}}\right)
$$

Differentiating $p_{\text {seq }}$ with respect to the government's incentives gives

$$
\frac{\partial p_{s e q}}{\partial\left[\Delta_{g}+\Delta p R\right]}=-\frac{k_{g}}{\left[\Delta_{g}+Q R\right]^{2}} \frac{\frac{k_{g}}{\left[\Delta_{g}+Q R\right]}}{\frac{k_{g}}{\left[\Delta_{g}+Q R\right]}+\frac{k_{c}}{\Delta_{c}}}<0 .
$$

Thus, in contrast to the simultaneous game, it is guaranteed in the sequential game that an increase 
in the incentives of the government to prevent a terror attack translates into a reduced equilibrium probability of a terror attack.

In which game is the probability of a terror attack larger? Comparing (13) and (20), it is easy to see that $p_{\text {seq }}<p_{\text {sim }}$ if and only if

$$
\frac{\alpha e}{\frac{k_{g}}{\left[\Delta_{g}+Q R\right]}+\frac{k_{c}}{\Delta_{c}}}<\frac{\alpha\left(\Delta_{g}+Q R\right)}{k_{g}},
$$

which can be simplified to

$$
\frac{\frac{\Delta_{g}+Q R}{k_{g}}}{\frac{\Delta_{c}}{k_{c}}}>e-1 \approx 1.71 .
$$

Thus, if the incentives of the government to prevent an attack relative to costs are substantially larger than the cost-benefit ratio for the minority community, then the equilibrium probability of a terror attack is lower in the sequential game.

\section{Discussion and Policy Implications}

\subsection{Mechanisms for Commitment}

Our results suggest that, whenever the minority community's reaction to an increase in government surveillance $s$ is to reduce their level of cooperation $i$, then it would be in the government's interest to commit to a lower level of $s$ than the equilibrium level. However, Section 6.3, in particular Proposition 5, shows that, under reasonable assumptions about the observability of its antiterrorism policy, the government cannot achieve commitment by simply "moving first". Rather, we argue that commitment requires either explicit mechanisms that constrain the policy choices of the government, mechanisms that restrict the government's preferences for reelection, or strategic delegation by voters to politicians with different preferences.

Checks and Balances on the Government's Actions. After 9/11, the United States and other Western democracies passed emergency laws and engaged in a range of aggressive counterterrorism measures such as coercive interrogation, ethnic profiling, interception of communications and preventive arrests and detention. Although these measures may have prevented potential terrorist attacks, ${ }^{6}$ they have also being widely criticized for violating human rights. The scholarly and policy argument in favor of these aggressive actions is that there is a trade-of between security and liberty, and in times of national emergencies such as the aftermath of $9 / 11$, the security-liberty balance should shift in favor of security (Posner and Vermeule 2007, Posner 2007).

Our analysis suggests that counter-majoritarian checks and balances on emergency legislation and the government's aggressive counterterrorism actions can be a useful tool to achieve com-

\footnotetext{
${ }^{6}$ The actual effectiveness of the most controversial of these measures - torture or enhanced interrogation, depending on one's point of view — is in dispute. While former Bush administration officials such as Vice President Dick Cheney claim that waterboarding prevented specific new terror attacks, these claims have not been verified.
} 
mitment. An important counter-majoritarian check is exercised by the judicial branch. Courts equipped with the power of judicial review can enforce constitutional commitments to rights and invalidate emergency legislation that infringes on human rights even if the legislation might work in preventing terrorism. When using its checks and balances power, the judiciary guarantees a certain level of rights protections and keeps the government's commitment to less aggressive counterterrorism actions. Our argument for judicial checks and balances does not require that the courts observe the counterterrorism actions chosen by the government perfectly. As long as the court's signal is close to the true policy with a sufficiently high probability, excessive counterterrorism can be deterred even by an imperfect court system.

An example of a law that creates judicial checks and balances and increases the cost of government surveillance is the Foreign Intelligence Surveillance Act (FISA). FISA prescribes procedures for the physical and electronic surveillance and collection of "foreign intelligence information" between "foreign powers" and "agents of foreign powers" (which may include American citizens and permanent residents suspected of being engaged in espionage and violating U.S. law on territory under United States control). The act limits warrantless surveillance and thus requires that the government either obtains a surveillance warrant by showing probable cause in a special court. Thus, the act increases the government's cost of engaging in surveillance and likely leads to a reduction of surveillance activity, relative to a scenario in which the government is completely unconstrained.

However, for the judicial checks and balances to work as a commitment device, the courts need to enforce the nation's laws and constitution even in times of emergency. A common observation is that "in times of war, the law falls silent" ("inter arma enim silent leges"). Courts may not necessarily enforce legal violations by executive officials in times of emergency. However, judicial review only works as an effective commitment device if breaking the laws is costly for government officials. This requires at least that elected officials who are considering breaking the laws face some probability of being punished for their behavior in a court of law. The commitment opportunity afforded by judicial review constraining government behavior disappears if there is a culture of impunity within the government, in particular for transgressions committed "in good faith".

Suppose that Congress passes a law that prohibits certain infringements of civil liberties and that this creates the expectation that the government will adhere to the law. If sanctions are not enforced ex-post, though, the government always has an incentive to increase its level of antiterrorist measures over the extent that the law allows for, and all these transgressions could be in "good faith" (i.e., undertaken with the sole objective of lowering the probability of a terrorist attack). However, if all officials who break the law can expect to be pardoned by the president because of their impeccable motivations that induced them to break the law, then the law effectively does not afford commitment to the government. We believe that this is an important and, to our knowledge, novel argument that applies, for example, to the question whether government officials should be prosecuted for ordering torture of suspected or actual terrorists, even if it were true that torture sometimes "works" in obtaining information that can be used to thwart terrorist attacks). 
Term limits. By definition, a government that faces a term limit has no incentive to adjust its policy in order to increase the likelihood to gain reelection. In most settings, this is an argument against term limits, as a government with a term limit has a lower incentive to work for the common good than one that can be reelected. However, in our model, stronger incentives to achieve the common good may actually have the perverse effect of making the achievement of the common good less likely in equilibrium. Whenever this is true, term limits are a welfare-improving institution in our setting.

Strategic delegation. In our model, politicians have preferences that are very similar to those of voters, except for their desire to win reelection. In a scenario in which the government plays a game with other actors such as here, it may well be the case that voters can obtain a higher equilibrium payoff if they strategically select the type of agent who plays the game for them. ${ }^{7}$ We now discuss several possible implementations of this idea in our framework.

The government in our model is of the type that James Madison describes in Federalist 57 where he argues that the best representative is one that works on achieving the common good but also is responsive to electoral pressures. ${ }^{8}$ However, our analysis suggests that such "Madisonian" representatives might lead to inefficient social outcomes. A mechanism to restrict the government's preference for reelection is to select a government that does not care for reelection (or, at least, puts a lower weight on the reelection payoff). Edmund Burke argued for this type of politicians who care exclusively about achieving the common good and have no direct preference for reelection. If we think of different politicians' preferences in our model as continuum from those Burkean trustees to the "Madisonian" representatives, then our analysis suggests that in the context of terrorism prevention it is beneficial to select a representative government more on the Burkean end of the spectrum.

One can also think of the cost function $c_{g}(s)$ as at least partially reflecting the preferences and attitudes of the policy maker. Different politicians such as George W. Bush and Barak Obama are likely to care differentially about civil liberties, and are therefore inclined to implement different anti-terror policies. Strategic delegation to a politician with different preferences can thus serve as a credible commitment device. The results of our model suggest that the representative voter should optimally delegate the execution of anti-terror policy to a politician who is more concerned about civil liberties or the nation's image in the world than the representative voter himself.

\subsection{Minority Rights and Terrorism Prevention}

Scholars have debated two important aspects of expanding the government's antiterrorism activities in its distributive aspects and its impact on fundamental human rights. Jeremy Waldron analyzes

\footnotetext{
${ }^{7}$ There are several models in political economy that explore the idea of strategic delegation to decision makers whose preferences differ from those of the pivotal voter. See, for example, Rogoff (1985), Messner and Polborn (2004), Dal Bo (2006) or Klumpp (2007).

${ }^{8}$ Andrew Rehfeld argues this is precisely the kind of representation that James Madison was defending in his contributions to The Federalist.
} 
the issue of distribution in the context of terrorism prevention and notes that not all members of society have their civil liberties and rights infringe equally. Members of minority groups are more likely to face civil liberties losses and this fact raises the question of fairness (Waldron 2003). In fact, it is quite plausible that the degree to which a particular anti-terror activity is perceived as impacting disproportionately the minority community influences the extent to which the policy leads to alienation. This may provide a justification for some security policies that appear blatantly inefficient given the nature of the terrorist threat. For example, the identity of people who have to undergo secondary (special) inspection at airports seems to be determined rather randomly. If, instead of also inspecting travelers whose appearance suggests strongly that they do not pose a terrorist threat (say, women over the age of 60), secondary inspections were targeted much more to Muslim-looking men between 20 and 40 years of age, then the probability of finding something relevant may slightly increase. However, such a discriminatory policy would also be certain to destroy much more crucially needed goodwill in the Muslim community, and may therefore overall be much less efficient than a policy of untargeted secondary inspections.

Researchers also note that ethnic and religious profiling in the context of terrorism prevention constitutes breaches fundamental human rights norms and raises issues of discrimination and equality under the law (Goldston 2006). If the government relies on ethnic, racial, or religious stereotypes in its counterterrorism action, such ethnic profiling breaches one of the most fundamental principles of law in a liberal democracy: each person must be treated as an individual, not as a member of a group. Furthermore, ethnic profiling trumps the presumption of innocence upon which criminal investigation is based in a rule of law system.

Our model suggests that electoral pressure to be successful in preventing terrorism induces the government to increase its targeting of ethnic and minority communities. The analysis shows that excessive government targeting minority communities can arise as an equilibrium outcome even if it is counterproductive (i.e., reduces the equilibrium security level).

\section{Conclusions}

In this paper, we show that electoral pressure to be successful in preventing terrorism induces the government to increase its level of anti-terrorism activities directed at ethnic and religious minority groups. However, the overall effect may be a decrease of security, because electoral pressure of being successful in terrorism prevention creates a commitment problem: Specifically, the government intensifies policies that are under its direct control, but the cooperation of minority communities, which may be crucial for the success of an anti-terror policy, decreases. This strategic effect may dominate the direct one so that an increase in electoral pressures has the effect of possibly increasing the likelihood of a terrorist attack. If the government can commit ex-ante, it will always do this in a way to increase the equilibrium cooperation of the minority community. We argue that the inherently imperfect observability of anti-terrorist activities makes it hard for the government to commit to enacting a policy that is not optimal for it ex-post, and we discuss several institutional 
features that may afford at least some degree of commitment.

It may be interesting to integrate a terrorist organization as an active player in our model framework of electoral accountability when the terrorist organization is also interested in influencing the government's future policy and/or the identity of the government. Such a model would likely require a multi-period dynamic framework, and is left for future research.

Finally, the general principle that we identify in this paper, namely the connection between increased electoral accountability and the possibility of a perverse effect on the policy outcome, can certainly be applied in other policy fields as well. The same causation mechanisms apply more generally whenever the government needs to cooperate with independent actors to achieve the desired policy outcome. For example, some environmental problems such as global warming require the cooperation of many countries. If electoral pressure to solve a particular problem increases in one country, the government of that country will increase its effort to reach a solution, but the governments of other countries may react to the change strategically in a way that partially offsets, or even more than offsets this direct effect. A similar framework may also be fruitful in other policy issues that require international cooperation, such as nuclear non-proliferation. 


\section{Appendix}

Proof of Proposition 3. The government's first order condition in the simultaneous game is given by (4). In the sequential game, the government's first order condition is

$$
-\left(\frac{\partial p(s, i)}{\partial s}+\frac{\partial p(s, i)}{\partial i} i^{\prime}(s)\right) \cdot\left[\Delta_{g}+Q \cdot R\right]-c_{g}^{\prime}(s)=0
$$

Note that the left hand side of (23) is smaller than the left hand side of (4) if and only if $i^{\prime}(s)<0$; in this case, the optimal $s$ is smaller in the sequential game than in the simultaneous game, and consequently (since $i^{\prime}(s)<0$ ), the optimal level of $i$ is larger in the sequential game.

Conversely, if $i^{\prime}(s)>0$, the left hand side of (23) is greater than the left hand side of (4); thus, in this case, the optimal $s$ is greater in the sequential game than in the simultaneous game, and consequently (since $i^{\prime}(s)>0$ ), the optimal level of $i$ is larger in the sequential game.

Proof of Proposition 4. The government maximizes (16). Suppose $\left[\Delta_{g}^{1}+Q^{1} R^{1}\right]<\left[\Delta_{g}^{2}+Q^{2} R^{2}\right]$, i.e., the electoral incentives are stronger in case 2 than in case 1 . Denote the solution of the government's problem in case 1 by $s^{i}$, and denote the corresponding equilibrium probability by $p^{i}$; for example, $p^{1}=p\left(s^{1}, i\left(s^{1}\right)\right)$, where $i(\cdot)$ is the community's reaction function. Optimality in case 1 requires that

$$
-p^{1}\left[\Delta_{g}^{1}+Q^{1} R^{1}\right]-c_{g}\left(s^{1}\right) \geq-p^{2}\left[\Delta_{g}^{1}+Q^{1} R^{1}\right]-c_{g}\left(s^{2}\right),
$$

as $s^{2}$ is a feasible choice and cannot get the government a higher payoff than the optimal action $s^{1}$. Analogously, optimality in case 2 requires that

$$
-p^{2}\left[\Delta_{g}^{2}+\Delta p^{2} R^{2}\right]-c_{g}\left(s^{2}\right) \geq-A^{1}\left[\Delta_{g}^{2}+\Delta p^{2} R^{2}\right]-c_{g}\left(s^{1}\right)
$$

Adding (24) and (25) and rearranging yields

$$
\left(p^{2}-p^{1}\right)\left[\Delta_{g}^{1}+Q^{1} R^{1}-\Delta_{g}^{2}+Q^{2} R^{2}\right] \geq 0
$$

Since the term in square brackets is negative by assumption, it must be true that $p^{1} \geq p^{2}$, as claimed.

Proof of Proposition 5. Consider first the if-part of the proposition. Observe that, if the government plays pure strategy $s^{*}$ in equilibrium, the community's belief must place probability 1 to the event that the government chooses action $s^{*}$, no matter what signal $x$ the minority community observes (as any observed signal is consistent with the government having chosen $s^{*}$ ). Given this belief, action $i^{*}$ maximizes the community's expected utility (by the fact that $i^{*}$ is an optimal response to $s^{*}$ in the simultaneous game). Finally, given that the community chooses $i^{*}$ independent of the signal received, the government's optimal action is $s^{*}$. This proves that $\left(s^{*}, i_{s e q}(x)=i^{*}\right.$ for all $\left.x\right)$ is a pure strategy perfect Bayesian equilibrium of the sequential game with imperfect observability. 
Consider now the only-if-part of the proposition. Assume, by way of contradiction, that $s=s^{\prime}$ in a perfect Bayesian equilibrium, where $s^{\prime}$ is not part of any pure strategy equilibrium of the simultaneous game. Since we have a pure strategy equilibrium, the community's belief must place probability 1 on $s^{\prime}$, and thus $i_{\text {seq }}(x)=i\left(s^{\prime}\right)$ for all $x$ (where $i(\cdot)$ is the optimal response function from the static game). However, since the community's action $i\left(s^{\prime}\right)$ is independent of the signal, it must be the case that $s^{\prime}$ maximizes the government's utility, given that the community plays $i\left(s^{\prime}\right)$, i.e. $s^{\prime}=s\left(i\left(s^{\prime}\right)\right)$. But this contradicts the assumption that $\left(s^{\prime}, i\left(s^{\prime}\right)\right)$ is not an equilibrium of the simultaneous game. 


\section{References}

Abadie, A. (2006). Poverty, political freedom, and the roots of terrorism. The American Economic Review 96, 50-56.

Bagwell, K. (1995). Commitment and observability in games. Games and Economic Behavior 8(2), 271-280.

Besley, T. (2005). Political selection. The Journal of Economic Perspectives 19(3), 43-60.

Blomberg, S., G. Hess, and A. Weerapana (2004). Economic conditions and terrorism. European Journal of Political Economy 20(2), 463-478.

Bueno de Mesquita, E. (2007). Politics and the suboptimal provision of counterterror. International Organization 61(01), 9-36.

Bueno de Mesquita, E. and E. Dickson (2007). The propaganda of the deed: Terrorism, counterterrorism, and mobilization. American Journal of Political Science 51(2), 364-381.

Chai, S.-K. (1993). An Organizational Economics Theory of Anti-Government Violence. Comparative Politics 26, 99-110.

Dal Bo, E. (2006). Committees with supermajority voting yield commitment with flexibility. Journal of Public Economics 90(4-5), 573-599.

de Mesquita, E. (2005). Conciliation, counterterrorism, and patterns of terrorist violence. International Organization 59(01), 145-176.

Enders, W. and T. Sandler (1993). The effectiveness of antiterrorism policies: A vectorautoregression-intervention analysis. The American Political Science Review 87(4), 829-844.

Enders, W. and T. Sandler (2006). The political economy of terrorism. Cambridge Univ Pr.

Fearon, J. (1999). Democracy, accountability, and representation, Chapter Electoral accountability and the control of politicians: selecting good types versus sanctioning poor performance, pp. 55-97. Cambridge University Press.

Fiorina, M. P. (1981). Retrospective voting in American national elections. Yale University Press New Haven, CT.

Gassebner, M., R. Jong-A-Pin, and J. Mierau (2007). Terrorism and electoral accountability: One strike, you're out! Economics Letters 100, 126-129.

Goldston, J. (2006). Ethnic profiling and counter-terrorism: Trends, dangers and alternatives. Open Society Institute.

Key, V. (1966). The responsible electorate. Vintage Books.

Klumpp, T. (2007). Strategic voting and conservatism in legislative elections. mimeo, Emory University.

Kydd, A. and B. Walter (2006). The strategies of terrorism. International Security 31 (1), 49-80.

Li, Q. (2005). Does Democracy Promote or Reduce Transnational Terrorist Incidents? Journal of Conflict Resolution 49(2), 278.

Manin, B. (1997). The principles of representative government. Cambridge Univ Pr. 
Messner, M. and M. Polborn (2004). Voting on majority rules. The Review of Economic Studies $71(1), 115-132$.

Posner, E. and A. Vermeule (2007). Terror in the Balance: Security, Liberty, and the Courts. Oxford University Press, USA.

Posner, R. (2007). Countering terrorism: Blurred focus, halting steps. Rowman \& Littlefield Publishers.

Powell, R. (2007a). Allocating defensive resources with private information about vulnerability. American Political Science Review 101 (04), 799-809.

Powell, R. (2007b). Defending against terrorist attacks with limited resources. American Political Science Review 101 (03), 527-541.

Rogoff, K. (1985). The optimal degree of commitment to an intermediate monetary target. The Quarterly Journal of Economics 100(4), 1169-1189.

Rosendorff, B. and T. Sandler (2004). Too much of a good thing?: The proactive response dilemma. Journal of Conflict Resolution 48(5), 657.

Sandler, T. and K. Siqueira (2006). Global terrorism: deterrence versus pre-emption. Canadian Journal of Economics 39(4), 1370-1387.

Waldron, J. (2003). Security and liberty: The image of balance. Journal of Political Philosophy 11(2), 191-210. 


\section{CESifo Working Paper Series}

for full list see www.cesifo-group.org/wp

(address: Poschingerstr. 5, 81679 Munich, Germany, office@cesifo.de)

2801 Evžen Kočenda and Jan Hanousek, State Ownership and Control in the Czech Republic, September 2009

2802 Michael Stimmelmayr, Wage Inequality in Germany: Disentangling Demand and Supply Effects, September 2009

2803 Biswa N. Bhattacharyay, Towards a Macroprudential Surveillance and Remedial Policy Formulation System for Monitoring Financial Crisis, September 2009

2804 Margarita Katsimi, Sarantis Kalyvitis and Thomas Moutos, "Unwarranted" Wage Changes and the Return on Capital, September 2009

2805 Christian Lessmann and Gunther Markwardt, Aid, Growth and Devolution, September 2009

2806 Bas Jacobs and Dirk Schindler, On the Desirability of Taxing Capital Income to Reduce Moral Hazard in Social Insurance, September 2009

2807 Hans Gersbach and Noemi Hummel, Climate Policy and Development, September 2009

2808 David E. Wildasin, Fiscal Competition for Imperfectly-Mobile Labor and Capital: A Comparative Dynamic Analysis, September 2009

2809 Johan Eyckmans and Cathrine Hagem, The European Union's Potential for Strategic Emissions Trading through Minimal Permit Sale Contracts, September 2009

2810 Ruediger Bachmann and Christian Bayer, The Cross-section of Firms over the Business Cycle: New Facts and a DSGE Exploration, October 2009

2811 Slobodan Djajić and Michael S. Michael, Temporary Migration Policies and Welfare of the Host and Source Countries: A Game-Theoretic Approach, October 2009

2812 Devis Geron, Social Security Incidence under Uncertainty Assessing Italian Reforms, October 2009

2813 Max-Stephan Schulze and Nikolaus Wolf, Economic Nationalism and Economic Integration: The Austro-Hungarian Empire in the Late Nineteenth Century, October 2009

2814 Emilia Simeonova, Out of Sight, Out of Mind? The Impact of Natural Disasters on Pregnancy Outcomes, October 2009

2815 Dan Kovenock and Brian Roberson, Non-Partisan 'Get-Out-the-Vote' Efforts and Policy Outcomes, October 2009 
2816 Sascha O. Becker, Erik Hornung and Ludger Woessmann, Catch Me If You Can: Education and Catch-up in the Industrial Revolution, October 2009

2817 Horst Raff and Nicolas Schmitt, Imports, Pass-Through, and the Structure of Retail Markets, October 2009

2818 Paul De Grauwe and Daniel Gros, A New Two-Pillar Strategy for the ECB, October 2009

2819 Guglielmo Maria Caporale, Thouraya Hadj Amor and Christophe Rault, International Financial Integration and Real Exchange Rate Long-Run Dynamics in Emerging Countries: Some Panel Evidence, October 2009

2820 Saša Žiković and Randall K. Filer, Hybrid Historical Simulation VaR and ES: Performance in Developed and Emerging Markets, October 2009

2821 Panu Poutvaara and Andreas Wagener, The Political Economy of Conscription, October 2009

2822 Steinar Holden and Åsa Rosén, Discrimination and Employment Protection, October 2009

2823 David G. Mayes, Banking Crisis Resolution Policy - Lessons from Recent Experience Which elements are needed for robust and efficient crisis resolution?, October 2009

2824 Christoph A. Schaltegger, Frank Somogyi and Jan-Egbert Sturm, Tax Competition and Income Sorting: Evidence from the Zurich Metropolitan Area, October 2009

2825 Natasa Bilkic, Thomas Gries and Margarethe Pilichowski, Stay in School or Start Working? - The Human Capital Investment Decision under Uncertainty and Irreversibility, October 2009

2826 Hartmut Egger and Udo Kreickemeier, Worker-Specific Effects of Globalisation, October 2009

2827 Alexander Fink and Thomas Stratmann, Institutionalized Bailouts and Fiscal Policy: The Consequences of Soft Budget Constraints, October 2009

2828 Wolfgang Ochel and Anja Rohwer, Reduction of Employment Protection in Europe: A Comparative Fuzzy-Set Analysis, October 2009

2829 Rainald Borck and Martin Wimbersky, Political Economics of Higher Education Finance, October 2009

2830 Torfinn Harding and Frederick van der Ploeg, Is Norway's Bird-in-Hand Stabilization Fund Prudent Enough? Fiscal Reactions to Hydrocarbon Windfalls and Graying Populations, October 2009

2831 Klaus Wälde, Production Technologies in Stochastic Continuous Time Models, October 2009 
2832 Biswa Bhattacharyay, Dennis Dlugosch, Benedikt Kolb, Kajal Lahiri, Irshat Mukhametov and Gernot Nerb, Early Warning System for Economic and Financial Risks in Kazakhstan, October 2009

2833 Jean-Claude Trichet, The ECB's Enhanced Credit Support, October 2009

2834 Hans Gersbach, Campaigns, Political Mobility, and Communication, October 2009

2835 Ansgar Belke, Gunther Schnabl and Holger Zemanek, Real Convergence, Capital Flows, and Competitiveness in Central and Eastern Europe, October 2009

2836 Bruno S. Frey, Simon Luechinger and Alois Stutzer, The Life Satisfaction Approach to Environmental Valuation, October 2009

2837 Christoph Böhringer and Knut Einar Rosendahl, Green Serves the Dirtiest: On the Interaction between Black and Green Quotas, October 2009

2838 Katarina Keller, Panu Poutvaara and Andreas Wagener, Does Military Draft Discourage Enrollment in Higher Education? Evidence from OECD Countries, October 2009

2839 Giovanni Cespa and Xavier Vives, Dynamic Trading and Asset Prices: Keynes vs. Hayek, October 2009

2840 Jan Boone and Jan C. van Ours, Why is there a Spike in the Job Finding Rate at Benefit Exhaustion?, October 2009

2841 Andreas Knabe, Steffen Rätzel and Stephan L. Thomsen, Right-Wing Extremism and the Well-Being of Immigrants, October 2009

2842 Andrea Weber and Christine Zulehner, Competition and Gender Prejudice: Are Discriminatory Employers Doomed to Fail?, November 2009

2843 Hadi Salehi Esfahani, Kamiar Mohaddes and M. Hashem Pesaran, Oil Exports and the Iranian Economy, November 2009

2844 Ruediger Bachmann and Christian Bayer, Firm-Specific Productivity Risk over the Business Cycle: Facts and Aggregate Implications, November 2009

2845 Guglielmo Maria Caporale, Burcu Erdogan and Vladimir Kuzin, Testing for Convergence in Stock Markets: A Non-Linear Factor Approach, November 2009

2846 Michèle Belot and Jan Fidrmuc, Anthropometry of Love - Height and Gender Asymmetries in Interethnic Marriages, November 2009

2847 Volker Nitsch and Nikolaus Wolf, Tear Down this Wall: On the Persistence of Borders in Trade, November 2009

2848 Jan K. Brueckner and Stef Proost, Carve-Outs Under Airline Antitrust Immunity, November 2009 
2849 Margarita Katsimi and Vassilis Sarantides, The Impact of Fiscal Policy on Profits, November 2009

2850 Scott Alan Carson, The Relationship between Stature and Insolation: Evidence from Soldiers and Prisoners, November 2009

2851 Horst Raff and Joachim Wagner, Intra-Industry Adjustment to Import Competition: Theory and Application to the German Clothing Industry, November 2009

2852 Erkki Koskela, Impacts of Labor Taxation with Perfectly and Imperfectly Competitive Labor Markets under Flexible Outsourcing, November 2009

2853 Cletus C. Coughlin and Dennis Novy, Is the International Border Effect Larger than the Domestic Border Effect? Evidence from U.S. Trade, November 2009

2854 Johannes Becker and Clemens Fuest, Source versus Residence Based Taxation with International Mergers and Acquisitions, November 2009

2855 Andreas Hoffmann and Gunther Schnabl, A Vicious Cycle of Manias, Crashes and Asymmetric Policy Responses - An Overinvestment View, November 2009

2856 Xavier Vives, Strategic Supply Function Competition with Private Information, November 2009

2857 M. Hashem Pesaran and Paolo Zaffaroni, Optimality and Diversifiability of Mean Variance and Arbitrage Pricing Portfolios, November 2009

2858 Davide Sala, Philipp J.H. Schröder and Erdal Yalcin, Market Access through Bound Tariffs, November 2009

2859 Ben J. Heijdra and Pim Heijnen, Environmental Policy and the Macroeconomy under Shallow-Lake Dynamics, November 2009

2860 Enrico Spolaore, National Borders, Conflict and Peace, November 2009

2861 Nina Czernich, Oliver Falck, Tobias Kretschmer and Ludger Woessmann, Broadband Infrastructure and Economic Growth, December 2009

2862 Evžen Kočenda and Martin Vojtek, Default Predictors and Credit Scoring Models for Retail Banking, December 2009

2863 Christian Gollier and Martin L. Weitzman, How Should the Distant Future be Discounted when Discount Rates are Uncertain?, December 2009

2864 Tiberiu Dragu and Mattias Polborn, Terrorism Prevention and Electoral Accountability, December 2009 